From perversion to purity

\section{MANCHESTER 1824}

Manchester University Press 


\title{
From perversion to purity
}

The stardom of Catherine Deneuve

\author{
edited by \\ Lisa Downing and Sue Harris
}

Manchester University Press

Manchester 
Copyright (C) Manchester University Press 2007

While copyright in the volume as a whole is vested in Manchester University Press, copyright in individual chapters belongs to their respective authors, and no chapter may be reproduced wholly or in part without the express permission in writing of both author and publisher.

Published by Manchester University Press

Altrincham Street, Manchester M1 7JA, UK

www.manchesteruniversitypress.co.uk

British Library Cataloguing-in-Publication Data

A catalogue record for this book is available from the British Library

Library of Congress Cataloging-in-Publication Data applied for

ISBN 9780719073380 hardback

First published 2007

$\begin{array}{llllllllllllllllllll}16 & 15 & 14 & 13 & 12 & 11 & 10 & 09 & 08 & 07 & 10 & 9 & 8 & 7 & 6 & 5 & 4 & 3 & 2 & 1\end{array}$

The publisher has no responsibility for the persistence or accuracy of URLs for any external or third-party internet websites referred to in this book, and does not guarantee that any content on such websites is, or will remain, accurate or appropriate.

Typeset in Sabon by Koinonia, Manchester 